\title{
PLUM GERMPLASM RESOURCES AND BREEDING IN ROMANIA
}

\author{
Madalina Butac ${ }^{1 . \#}$, Mihai Botu ${ }^{2,3}$, Madalina Militaru ${ }^{1}$, Craisor Mazilu ${ }^{1}$, Ion Dutu ${ }^{1}$, \\ and Silvia Nicolae ${ }^{1}$

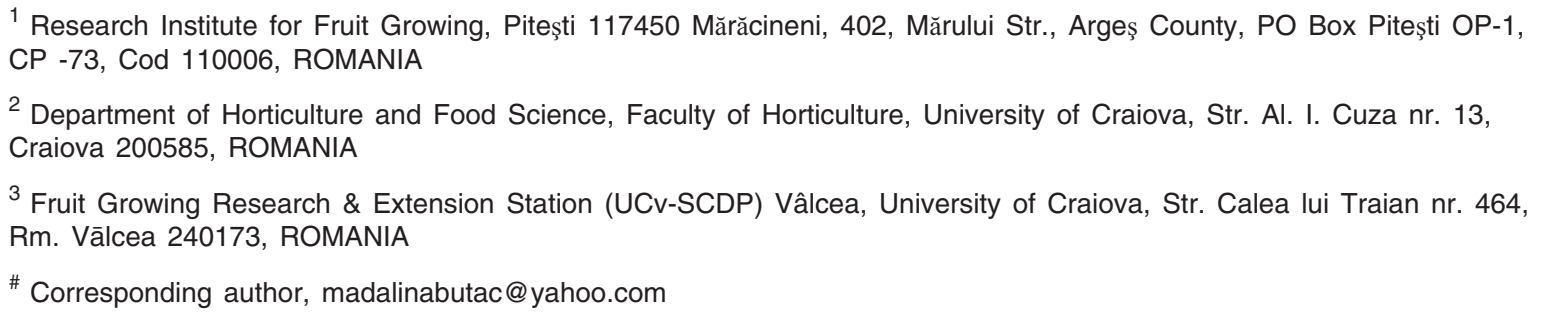

Communicated by Gunārs Lācis

In Romania, work on identification, conservation and evaluation of fruit genetic resources activities was initiated in 1970 in order to limit the loss of biodiversity. There are rich sources of germplasm located in two research centres: RIFG Pitesti with 642 accessions and UCV-SCDP Vâlcea with 361 accessions, representing wild species, local populations, named cultivars, breeder's selections and rootstocks. Observations were made according to the IBPGR Prunus descriptors updated by the ECP/GR Prunus Working Group. The following genetic resources from the Piteşti and Vâlcea collections were used in a breeding programme in the development of several plum cultivars: 'Grase de Becs', 'Carpatin', 'lalomiža', 'Kirke', 'Wilhelmina Späth' (for resistance / tolerance to Plum pox virus); 'Vinete romāneşti', 'Tuleu timpuriu', 'Anna Späth' (for late blooming), 'Tuleu gras', 'Vâlcean' (for fruit quality), 'Stanley', 'Pescăruş', 'Centenar' (for productivity), and 'Diana' (for self-fertility). The plum rootstock breeding programme used the following genotypes as sources of genes: 'Rosior văratec', 'Brompton', 'Renclod Verde', 'Pixy', 'Saint Julien A', 'Albe mici', 'Scolduş', 'Porumbar', etc. Breeding using the germplasm in these collections resulted in the release of 40 cultivars and 11 generative and vegetative rootstocks.

Key words: plum germplasm, breeding, genitors, cultivars, rootstocks.

\section{INTRODUCTION}

Biodiversity is very important for humanity according to the Convention on Biological Diversity signed by more than 150 countries, at the Earth Summit in Rio de Janeiro in 1992 (Botu et al., 2017). Plum is considered the second most important fruit tree crop produced in temperate climates (Botu et al., 2012) and the most important fruit tree crop in Romania (Butac et al., 2011; Coman et al., 2012).

Romania is a country located in Southeastern Europe, which has good environmental conditions for many fruit species in the wild or under cultivation. Numerous genetic resources of plum, apple, pear, sweet and sour cherry, peach, apricot, walnut, hazelnut, sweet chestnut, and berries are present (Botu et al., 2017).
Over 30-40 years ago, many countries started work on identification, collection, and conservation in field collections and gene banks, for evaluation and use of genetic resources in national and international programmes. The oldest fruit tree collections were established at Teynham, Kent (England) in 1533, at Hessen, Saxony (Germany) in 1542, at Pradel (France) in 1608, at Arad (Romania) in 1877 etc. (Branişte et al., 2006; Botu et al., 2017).

In Romania, work on identification, conservation and evaluation of fruit genetic resources was initiated in 1970 in order to limit the loss of the biodiversity due to genetic vulnerability. There are rich collections of plum germplasm for development of cultivars and rootstocks in two research centres: Research Institute for Fruit Growing (RIFG) Pitesti with 642 accessions and Fruit Growing Research and Ex- 
OVERVIEW OF EX SITU PLUM COLLECTIONS IN ROMANIA

\begin{tabular}{|c|c|c|c|c|c|c|c|}
\hline No. & Centre & $\begin{array}{l}\text { Type of } \\
\text { collections }\end{array}$ & $\begin{array}{c}\text { Species and } \\
\text { interspecific } \\
\text { hybrids }\end{array}$ & Local accessions & $\begin{array}{c}\text { Foreign } \\
\text { accessions }\end{array}$ & $\begin{array}{l}\text { Other (biotypes, } \\
\text { hybrids, mutants, } \\
\text { etc.) }\end{array}$ & $\begin{array}{r}\text { Total no. of } \\
\text { accessions }\end{array}$ \\
\hline \multirow[t]{3}{*}{1} & RIFG Pitesti & Cultivars & 7 & 183 & 320 & 40 & 550 \\
\hline & & Rootstocks & 0 & 82 & 10 & 0 & 92 \\
\hline & TOTAL RIFG & & 7 & 265 & 330 & 40 & 642 \\
\hline \multirow[t]{4}{*}{2} & UCv-SCDP Vâlcea & Cultivars & 27 & 56 & 125 & 35 & 216 \\
\hline & & Rootstocks & & 86 & 21 & 11 & 118 \\
\hline & TOTAL ECv-SCDP & & 27 & 142 & 146 & 46 & 361 \\
\hline & GENERAL TOTAL & & 34 & 407 & 476 & 86 & 1003 \\
\hline
\end{tabular}

tension Station (UCv-SCDP) Vâlcea with 361 accessions, representing wild species, local populations, named cultivars, breeder's selections and rootstocks.

The genetic resources preserved ex situ are very valuable and can be useful for breeding new cultivars and rootstocks. The success of any breeding programme depends on the existence of a rich source of valuable germplasm (Cociu et al., 1997; Butac et al., 2011).

\section{MATERIAL AND METHODS}

Presently, in Romania there are plum collections in two centres: RIFG Pitesti and UCv-SCDP Vâlcea. Ex situ conservation of accessions is done by different methods: conservation in the field collections (at RIFG Pitesti and UCv-SCDP Vâlcea), conservation in plastic containers and cryoconservation at $-196{ }^{\circ} \mathrm{C}$ in liquid nitrogen (at UCv-SCDP Vâlcea) (Braniste et al., 2006; Botu et al., 2008; Butac et al., 2011). At RIFG Pitesti, the plum cultivar collection established in 1997 includes 550 accessions, and the plum rootstock collection established in 2009 includes 92 accessions. At SCDP Vâlcea, the plum collections established in 1989, 1993, and 1996, include 361 accessions (species, cultivars and rootstocks). The accessions are arranged according to the ripening season. They are grafted on Myrobalan rootstock, spaced at 4 by $4 \mathrm{~m}$ (at RIFG Pitesti) and 5 by $4 \mathrm{~m}$, respectively (at Ucv-SCDP Vâlcea). Each genotype is a variant and each variant has $2-5$ replications $(1$ tree $=1$ replication $)$.

Between 2000-2017, in these collections of cultivars and rootstocks, observations have been made regarding phenology, productivity, vigour, fruit quality, resistance/tolerance to diseases and pests, resistance to low temperatures, resistance to frost, etc. in order to select genitors for future breeding. The observations and measurements were made according to the IBPGR Prunus descriptors updated by the ECP/GR Prunus Working Group within the Genres CT95 No. 61 project "International network on Prunus genetic resources".

The hybridisation and selection work was carried out in the plum experimental fields of the two research centres (RIFG Piteşti and UCv-SCDP Vâlcea). Current methods involved controlled cross-pollination and repeated positive selection in all development stages of hybrids.

\section{RESULTS}

In the Pitesti and Vâlcea centres there are a total of 1003 accessions (cultivars and rootstocks), of which: 34 are species and interspecific hybrids, 407 are local cultivars, 476 are foreign cultivars and rootstocks, and 86 are other genotypes (biotypes, hybrids, mutants, etc.) (Table 1).

Regarding the germplasm collections, one of the Romanian breeder's objectives is to enrich genetic resources by exchange of biological material with similar institutions, as well as by exploring the natural flora. Another objective is to identify new potential genitors for future breeding work (Table 2).

Table 2

GENITORS USED IN THE BREEDING WORK OF PLUM CULTIVARS IN ROMANIA

\begin{tabular}{|c|c|c|}
\hline No. & Objectives & Genitors \\
\hline 1 & Basic genitors & $\begin{array}{l}\text { Tuleu gras, Centenar, Carpatin, Tuleu } \\
\text { timpuriu, Tita, Alina, Record, Minerva, } \\
\text { Piteştean, Dāmboviža, Albatros, Pescăruş, } \\
\text { Sarmatic, Vâlcean, Silvia, Iulia, Stanley }\end{array}$ \\
\hline 2 & $\begin{array}{l}\text { Resistance / } \\
\text { tolerance to PPV }\end{array}$ & $\begin{array}{l}\text { Oneida, Kirke, Grase de Becs, Grase de } \\
\text { Peşteana, Agen de Sirăuži, Boambe de } \\
\text { Leordeni, Ontario, Wilhelmina Späth, Kirke, } \\
\text { Jojo, Andreea }\end{array}$ \\
\hline 3 & Fruit quality & $\begin{array}{l}\text { d`Agen, Agen 707, Grand Prize, Vision, } \\
\text { Valor, Oneida, Čačanska rodna, Grase } \\
\text { romānesti, Agen de Sirăuži, Vâlcean, On- } \\
\text { tario, Renclod Althan, Renclod violet, Re- } \\
\text { cord, Vânăt de Italia, Andreea, Agent, } \\
\text { Romanža, Voyageur, Hanita, Haganta, Mi- } \\
\text { nerva, Debreceny, Pescăruş, Ozark premier }\end{array}$ \\
\hline 4 & Earliness & $\begin{array}{l}\text { Early Rivers, Ruth Gerstetter, Diana, } \\
\text { Ialomiža, Čačanska lepotica, Čačanska ranna }\end{array}$ \\
\hline 5 & Lateness & $\begin{array}{l}\text { Anna Späth, Vinete romāneşti, Valor, Presi- } \\
\text { dent, Jojo }\end{array}$ \\
\hline 6 & Self-fertility & $\begin{array}{l}\text { Stanley, Anna Späth, Bluefre, Ialomiža, Di- } \\
\text { ana, Romanža, Čačanska lepotica, Andreea }\end{array}$ \\
\hline 7 & Productivity & $\begin{array}{l}\text { Stanley, Anna Späth, Bluefre, Standard, } \\
\text { Grase de Becz, Čačanska lepotica }\end{array}$ \\
\hline 8 & Low vigour & Stanley, Bluefre, Wilhelmina Späth \\
\hline
\end{tabular}


In the breeding work for cultivars, the main objectives are: improvement of the old Romanian cultivars 'Tuleu gras', 'Vinete romanesti', and 'Grase romanesti'; extension of the fruit ripening season; improvement of fruit quality for fresh market; tolerance/resistance to Plum Pox Virus (PPV); self-fertility; increased productivity; and decreased tree vigour.

Taking into account these objectives, breeding for new cultivars used the following different genitors: 'Grase de Becs', 'Carpatin', 'Ialomiža', 'Kirke', 'Wilhelmina Späth' (for resistance / tolerance to Plum pox virus), 'Vinete romāneşti', 'Tuleu timpuriu', 'Anna Späth' (for late blooming), 'Tuleu gras', 'Vâlcean' (for fruit quality), 'Stanley', 'Pescăruş', 'Centenar' (for productivity); 'Diana', and 'Andreea' (for self-fertility) (Table 2).

The plum cultivar breeding programme began 60 years ago, using various breeding methods (controlled hybridisation, open pollination, selection from wild populations, and mutagenesis).

As a results of breeding, 40 new varieties with very good agrobiological characteristics were registered, patented or have patents pending. Conventional breeding methods (crossing) were used to modify the genetic structure of quantitative traits of new plum cultivars. Some of the phenotype characteristics were improved and others did not show positive changes. For example, regarding fruit size, most of the cultivars obtained in Romania have larger fruits than old cultivars like 'Tuleu gras' and 'Grase româneşti'. The productivity of some new cultivars was improved. Male sterility from 'Tuleu gras' was passed on to the whole offspring, with all cultivars obtained from this maternal parent being male sterile. Regarding the ripening time, most of the new cultivars are earlier than the old cultivars (for example, 'Centenar', 'Tuleu timpuriu', 'Carpatin', 'Tita' are earlier than 'Tuleu gras'). A very good genetic gain was achieved regarding tolerance to Plum pox virus. Several cultivars like 'Ialomiža', 'Carpatin', 'Alina', 'Roman', 'Romanža', 'Agent', 'Andreea' etc. have demonstrated tolerance to PPV (Tables 3-6).

Very good results have been obtained in the rootstock breeding programmes started 50 years ago in the Vâlcea and Piteşti centres. In the breeding programmes for plum rootstocks the main objectives are: low to medium vigour;

THE GENETIC GAIN OF NEW CULTIVARS OBTAINED FROM 'TULEU GRAS' AND HIS OFFSPRING

\begin{tabular}{|c|c|c|c|c|c|}
\hline No. & Cultivar & $\begin{array}{l}\text { Year of } \\
\text { registration }\end{array}$ & Parents & $\begin{array}{l}\text { Breeding method } \\
\text { used }\end{array}$ & Genetic gain - trait modified \\
\hline 1 & Tuleu timpuriu & 1967 & Tuleu gras $\times$ Pźche & Simple cross & Earlier and more productive than Tuleu gras \\
\hline 3 & Tuleu dulce & 1968 & Tuleu gras $\times$ d'Agen & Simple cross & More sweet than Tuleu gras \\
\hline 4 & Centenar & 1978 & Tuleu gras $\times$ Early Rivers & Simple cross & $\begin{array}{l}\text { Earlier and more productive than Tuleu gras; a few later } \\
\text { than Early Rivers }\end{array}$ \\
\hline 5 & Albatros & 1979 & Tuleu gras o.p. & Open pollination & Earlier and bigger fruit than Tuleu gras \\
\hline 6 & Dambovita & 1981 & Tuleu gras $\times$ Anna Späth & Simple cross & Later and bigger fruit than Tuleu gras \\
\hline 7 & Pitestean & 1982 & Tuleu timpuriu $\times$ Early Rivers & Pyramid cross & Earlier and bigger fruit than Tuleu timpuriu \\
\hline 8 & Carpatin & 1982 & Tuleu gras $\times$ Early Rivers & Simple cross & Earlier and bigger fruit than Tuleu gras; tolerant to PPV \\
\hline 9 & Minerva & 1984 & Tuleu timpuriu $\times$ Early Rivers & Pyramid cross & Earlier than Tuleu timpuriu \\
\hline 10 & Flora & 1989 & Tuleu gras $\times$ Renclod violet & Simple cross & Earlier and bigger fruit than Tuleu gras; tolerant to PPV \\
\hline 12 & Baragan 17 & 1990 & Tuleu gras $\times$ Early Rivers & Simple cross & Earlier than Tuleu gras \\
\hline 13 & Tita & 1991 & Tuleu gras - irradiated stones & Mutagenesis & $\begin{array}{l}\text { Earlier and bigger fruit than Tuleu gras; very good fruit } \\
\text { quality }\end{array}$ \\
\hline 14 & Alina & 1991 & Tuleu gras - irradiated stones & Mutagenesis & $\begin{array}{l}\text { Earlier and bigger fruit than Tuleu gras; very good fruit } \\
\text { quality; Tolerant to PPV }\end{array}$ \\
\hline 15 & Iulia & 2002 & Tuleu gras $\times$ Renclod Althan & Simple cross & Earlier and bigger fruit than Tuleu gras \\
\hline 16 & Ivan & 2003 & Tuleu gras $\times$ Vānăt de Italia & Simple cross & Earlier and bigger fruit than Tuleu gras \\
\hline 17 & Jubileu 50 & 2003 & Tuleu gras $\times$ De Bistriža & Simple cross & $\begin{array}{l}\text { Earlier, bigger fruit and more productive than Tuleu } \\
\text { gras }\end{array}$ \\
\hline 18 & Roman & 2004 & Tuleu gras $\times$ Early Rivers & Simple cross & Earlier and bigger fruit than Tuleu gras; tolerant to PPV \\
\hline 19 & Dani & 2004 & Tuleu gras $\times$ Grase romāneşti & Simple cross & $\begin{array}{l}\text { Later than Tuleu gras, but earlier and bigger fruit than } \\
\text { Grase romanesti }\end{array}$ \\
\hline 22 & Elena & 2005 & Tuleu gras $\times$ Stanley & Simple cross & Later than Tuleu gras and Stanley \\
\hline 23 & Topval & 2010 & Tuleu gras $\times$ Stanley & Simple cross & Earlier and bigger fruit than Tuleu gras; tolerant to PPV \\
\hline
\end{tabular}


THE GENETIC GAIN OF NEW CULTIVARS OBTAINED FROM 'GRASE ROMANESTI'

\begin{tabular}{|c|c|c|c|c|c|}
\hline No. & Cultivar & Year of registration & Parents & Breeding method used & Genetic gain - trait modified \\
\hline 1 & Gras ameliorat & 1968 & Grase romanesti - self pollination & Auto pollination & $\begin{array}{l}\text { Earlier, bigger and more sweet fruit; } \\
\text { tolerant to PPV }\end{array}$ \\
\hline
\end{tabular}

Table 5

THE GENETIC GAIN OF NEW CULTIVARS OBTAINED FROM 'VINETE ROMANESTI'

\begin{tabular}{|c|c|c|c|c|c|}
\hline No. & Cultivar & Year of registration & Parents & Breeding method used & Genetic gain - trait modified \\
\hline 1 & Vinete romāneşti 300 & 1970 & Vinete romāneşti selection & Selection & $\begin{array}{l}\text { More productive and tolerant to PPV } \\
\text { than Vinete romāneşti }\end{array}$ \\
\hline
\end{tabular}

Table 6

THE GENETIC GAIN OF NEW CULTIVARS OBTAINED FROM OTHER CULTIVARS

\begin{tabular}{|c|c|c|c|c|c|}
\hline No. & Cultivar & $\begin{array}{l}\text { Year of } \\
\text { registration }\end{array}$ & Parents & $\begin{array}{l}\text { Breeding method } \\
\text { used }\end{array}$ & Genetic gain - trait modified \\
\hline 1 & Silvia & 1979 & Renclod Althan $\times$ Early Rivers & Simple cross & More productive than both parents \\
\hline 3 & Ialomita & 1981 & Renclod Althan $\times$ Early Rivers & Simple cross & $\begin{array}{l}\text { Self-fertile; earlier than Renclod Althan. } \\
\text { Tolerant to PPV }\end{array}$ \\
\hline 4 & Diana & 1983 & Renclod Althan $\times x$ Early Rivers & Simple cross & Self-fertile; earlier than Renclod Althan \\
\hline 5 & Record & 1983 & Renclod violet o.p. & Open pollination & $\begin{array}{l}\text { Bigger fruit, more productive than Renclod } \\
\text { violet }\end{array}$ \\
\hline 6 & Vâlcean & 1990 & $\begin{array}{l}\text { H 8/12 (R.C. Althan } \times \text { Wilhelmina Späth) } \times \\
\text { H 5/23 (R.C. Althan x Early Rivers) }\end{array}$ & Pyramid cross & $\begin{array}{l}\text { Earlier, bigger and more sweet fruit than both } \\
\text { parents }\end{array}$ \\
\hline 7 & $\begin{array}{l}\text { Renclod de } \\
\text { Caransebes }\end{array}$ & 1991 & Renclod Althan $\times$ Wilhelmina Späth & Simple cross & Earlier than both parents \\
\hline 8 & Andreea & 2000 & H 27/87 OP & Open pollination & $\begin{array}{l}\text { More sweet than mother parent; tolerant to } \\
\text { PPV }\end{array}$ \\
\hline 9 & Delia & 2002 & Vānăt de Italia × Anna Späth & Simple cross & $\begin{array}{l}\text { Later than Vânăt de Italia; lesser vigour than } \\
\text { both parents }\end{array}$ \\
\hline 10 & Agent & 2004 & Open pollination & Selection & $\begin{array}{l}\text { More sweet fruit; } \\
\text { tolerant to PPV }\end{array}$ \\
\hline 11 & Doina & 2004 & Anna Späth $\times$ Renclod Althan & Simple cross & Earlier than both parents \\
\hline 12 & Matilda & 2004 & Anna Späth $\times$ d'Agen - irradiated with $\mathrm{Co}^{60}$ & Simple cross & More productive than Anna Späth \\
\hline 13 & Zamfira & 2005 & Anna Späth $\times$ Renclod Althan & Simple cross & $\begin{array}{l}\text { Later than Anna Späth; } \\
\text { tolerant to PPV }\end{array}$ \\
\hline 14 & Alutus & 2010 & $\begin{array}{l}(\text { R.C. Althan } \times \text { Early Rivers }) \times(\text { R.C. Althan } \times \\
\text { Wilhelmina Späth }) \times \text { mixed pollen }\end{array}$ & Pyramid cross & $\begin{array}{l}\text { Later and bigger fruit than both parents; } \\
\text { tolerant to PPV }\end{array}$ \\
\hline 15 & Romanta & 2012 & Stanley $\times$ Vâlcean & Simple cross & $\begin{array}{l}\text { Bigger fruit than Stanley } \\
\text { More productive than Vâlcean; tolerant } \\
\text { to PPV }\end{array}$ \\
\hline
\end{tabular}

tolerance to PPV and foliar diseases; easy propagation; adaptability to heavy soil; good anchorage in the soil; good compatibility with commercially propagated cultivars and positive influence on precocity, yield and fruit quality. The following genotypes have been used as sources of genes to achieve these goals over time: 'Roşior văratec', 'Brompton', 'Renclod Verde', 'Pixy', 'Saint Julien A', 'Albe mici', 'Scolduş', 'Porumbar', etc. (Table 7).

The new rootstocks obtained in Romania are easier to propagate, have lower vigour, are adapted to heavy soils and are resistant to major diseases. Among the newly developed rootstocks are: 'Oteşani 8', 'Oteşani 11', 'Miroval', 'Rival',
'Pinval', 'Corval', 'Oltval' (obtained at UCV-SCDP Vâlcea); 'Mirobolan C5', 'Mirobolan dwarf', 'Adaptabil' and 'Mirodad 1' (obtained at RIFG Piteşti) (Table 8).

\section{DISCUSSION}

Most of the Romanian accessions belong to Prunus domestica, Prunus insititia, Prunus cerasifera, Prunus spinosa and Prunus salicina (Botu et al., 2008, 2017; Butac et al., 2010).

The evaluation of accessions from collections led to the creation of a database. A large number of genotypes (292), 
Many of the cultivars obtained in the Romanian breeding GENITORS USED IN THE BREEDING WORK OF PLUM ROOTSTOCKS

\begin{tabular}{|c|c|c|}
\hline No. & Species & Genitors \\
\hline 1 & Prunus domestica L. & $\begin{array}{l}\text { Roşior văratec, Renclod verde, Bromp- } \\
\text { ton, Oteşani } 8 \text {, Voineşti B }\end{array}$ \\
\hline 2 & Prunus cerasifera Ehrh & $\begin{array}{l}\text { Corcoduş 163, Corcoduş } 169, \mathrm{C} 2, \mathrm{C} 3 \text {, } \\
\mathrm{C} 4, \mathrm{C} 10, \mathrm{C} 12, \mathrm{C} 13, \mathrm{C} 16, \mathrm{C} 17, \mathrm{BN} 4 \mathrm{Kr}\end{array}$ \\
\hline 3 & Prunus insititia Juss & $\begin{array}{l}\text { Pixy, Oteşani 11, Albe mici, GF 655.2, } \\
\text { Saint Julien A, Scolduş, Poliza de } \\
\text { Nurcia }\end{array}$ \\
\hline 4 & Prunus spinosa L. & $\begin{array}{l}\text { Porumbar de Iaşi, Porumbar A, } \\
\text { Porumbar D-PL }\end{array}$ \\
\hline 5 & Prunus besseyi Bailey & Brooks, $P$. besseyi selections \\
\hline 6 & $\begin{array}{l}\text { Prunus tomentosa } \\
\text { Thunb. }\end{array}$ & Orient, 473,474 \\
\hline
\end{tabular}

especially local varieties, have already been introduced into the European Gene Bank of Prunus; respectively, 181 genotypes belong to Prunus domestica, 38 genotypes belong to Prunus cerasifera, 67 belong to Prunus insititia and 6 belong to other species (Maggioni et al., 2010).

Regarding the breeding work for cultivars, the same objectives, genitors and methods were reported by Botu et al. in 2012. The breeding work created a large variability which was very important for future fruit growing in Romania (Butac et al., 2010; Butac et al., 2013). programme are being cultivated in other European countries ('Tita' in the Netherlands; 'Pitestean' in Germany and Poland; 'Carpatin' in Czech Republic and Poland; 'Tuleu timpuriu' in Bulgaria, etc.) (Butac et al., 2011).

Botu et al. in 2012 reported similar results concerning the modification of the genetic structure in new plum cultivars obtained in Romania. For example, 'Andreea' and 'Agent' cvs, were described as tolerant to plum pox virus. The male sterility of the plum cultivars obtained from 'Tuleu gras' cv. was also described by Botu and collaborators in the same year.

Regarding the breeding work for rootstocks the same objectives, genitors and methods were reported by Braniste and Butac in 2006, Mazilu et al. in 2013. In 2013, Mazilu and his collaborators reported that the main objectives in rootstock breeding are low vigour and good compatibility with commercially cultivars, because the main rootstocks used in the past in Romania and also in Europe were 'Myrobalan' seedlings. Blazec and Pistekova in 2009 and 2012, Kaufmane et al. in 2007 and Sosna in 2002 wrote that 'Myrobalan' rootstock is very vigorous and has insufficient compatibility with some cultivars. The new rootstocks developed in Romania were described by Botu et al. in 2006, Dutu et al. in 1993 and Mazilu et al. in 2013.

Table 8

THE PLUM ROOTSTOCKS OBTAINED IN ROMANIA AND THE GENETIC GAIN ACHIEVED FOR CERTAIN CHARACTERISTICS

\begin{tabular}{|c|c|c|c|c|c|}
\hline No. & $\begin{array}{l}\text { Rootstock } \\
\text { name }\end{array}$ & $\begin{array}{l}\text { Year of } \\
\text { registration }\end{array}$ & Parents & $\begin{array}{l}\text { Breeding method } \\
\text { used }\end{array}$ & Genetic gain - trait modified \\
\hline \multicolumn{6}{|c|}{ Valcea center } \\
\hline 2 & Otesani 11 & 1987 & $\begin{array}{l}\text { Selection in } P \text {. insititia } \\
\text { population }\end{array}$ & Selection & $\begin{array}{l}\text { Clonal rootstock with better grafting compatibility and induced } \\
\text { lower vigour than Myrobalan }\end{array}$ \\
\hline 3 & Miroval & 1998 & $\begin{array}{l}\text { Selection in } P \text {. cerasifera } \\
\text { population }\end{array}$ & Simple cross & Clonal rootstock with high multiplication capacity than Myrobalan \\
\hline 4 & Rival & 2003 & $\begin{array}{l}\text { Saint Julien } \mathrm{H} 2 \times P \text {. } \\
\text { insititia }\end{array}$ & Simple cross & Clonal rootstock with high multiplication capacity than Myrobalan \\
\hline 5 & Corval & 2005 & $\begin{array}{l}\text { Selection in } P \text {. cerasifera } \\
\text { population }\end{array}$ & Simple cross & Clonal rootstock with high multiplication capacity than Myrobalan \\
\hline 6 & Oltval & 2005 & $\begin{array}{l}(P . \text { besseyi } \times P . \\
\text { americana }) \times P \text {. cerasifera }\end{array}$ & Simple cross & Clonal rootstock with high multiplication capacity than Myrobalan \\
\hline 7 & Pinval & 2005 & Scolduş open pollination & Simple cross & Clonal rootstock with high multiplication capacity than Myrobalan \\
\hline \multicolumn{6}{|c|}{ Pitesti centre } \\
\hline 1 & Mirobolan C5 & 1999 & $\begin{array}{l}\text { Selection in } P \text {. cerasifera } \\
\text { population }\end{array}$ & Simple cross & Seedling rootstock with good compatibility with all plum cultivars \\
\hline 2 & $\begin{array}{l}\text { Mirobolan } \\
\text { dwarf }\end{array}$ & 1999 & Selection in wild flora & Simple cross & Seedling rootstock which induced lower vigour than Myrobalan \\
\hline 3 & $\begin{array}{l}\text { Adaptabil (for } \\
\text { peach and } \\
\text { plum) }\end{array}$ & 2000 & $\begin{array}{l}P . \text { besseyi } \times \text { mixed pollen } \\
(P . \text { cerasifera, } \\
P . \text { domestica, } P \text {. persica, } \\
P . \text { armeniaca })\end{array}$ & $\begin{array}{l}\text { Inter specific } \\
\text { cross }\end{array}$ & $\begin{array}{l}\text { Clonal rootstock with high multiplication capacity than Myrobalan; } \\
\text { more resistant to heavy soils than Myrobalan }\end{array}$ \\
\hline 4 & Mirodad 1 & 2017 & $\begin{array}{l}\text { Mirobolan dwarf } x \\
\text { Adaptabil }\end{array}$ & $\begin{array}{l}\text { Inter specific } \\
\text { cross }\end{array}$ & Clonal rootstock which induced lower vigour than Myrobalan \\
\hline
\end{tabular}




\section{CONCLUSIONS}

The genetic resources preserved ex situ and in situ are very important and can be used for breeding new cultivars and rootstocks. The success of any breeding programme depends on the existence of a rich source of valuable germplasm. In Romania there are very rich plum collections. Over time different genitors were used in plum breeding activities.

As a result of breeding, 40 new varieties and 11 new rootstocks were registered. Modern orchards can be established with some of these cultivars and rootstocks, which were using different breeding methods.

\section{ACKNOWLEDGEMENTS}

This paper was published under the projects ADER 3.3.1/2015 and ADER 3.2.2/2015, funded by the Ministry of Agriculture and Rural Development Bucharest, Romania.

\section{REFERENCES}

Anonymous (2011). ECPGR European Prunus Database. List of Prunus passport data and descriptors, September 2011. Available from: http://www.ecpgr.cgiar.org/fileadmin/templates/ecpgr.org/upload/ NW_and_WG_UPLOADS/Prunus/EPDB_New_list_of_descriptors_ 2011.pdf (accessed 20.04.2019).

Blažek, J., Pištěková, I. (2009). Preliminary evaluation results of new plum cultivars in a dense planting. Hort. Sci. (Prague), 36 (2), 45-54.

Blažek, J., Pištěková, I. (2012). Initial results from the evaluation of plum cultivars grown in a very dense planting. Acta Hort., 968, 99-108.

Botu, I., Achim, Gh., Botu, M., Preda, S., Butac, M. (2006). New plum rootstocks intended for intensive plantings. I Symposium on Plum of Serbia. Institute Serbia, Fruit and Grape Research Centre - Cacak. Book of Abstracts.

Botu, M., Botu, I., Vicol, A., Neagoe, A., Vişanu, F. (2008). Biodiversitatea pomicolă - conservare şi utilizare, la SCDP Vâlcea [Fruit tree Biodiversity - conservation and using at RSFG Valcea]. In: Lucrările colocviului nažional privind gestionarea resurselor genetice din pomicultură, pp. 52-55 (in Romanian).

Botu, I., Botu, M., Papachatzis, A., Cosmulescu, S., Preda, S. (2012). Evaluation of plum culture: Constrains and perspectives. Acta Hort., 968, 19-25.
Botu, M., Botu, I., Preda, S., Achim, Gh., Vicol, A. (2012). Genetic gain achieved in plum breeding programmes in Romania. Acta Hort., 968, 47-55.

Botu, M., Botu, I., Achim, Gh., Preda, S., Scutelnicu, A., Giura, S. (2017). Conservation of fruit tree genetic resources and their use in the breeding process. Ann. Valahia Univ. Targoviste, 11 (1), 66-69.

Braniste, N., Butac, M. (2006). Fondul de germoplasmă la speciile pomicole, de arbuşti fructiferi şi căpşun din colecžiile din România [Germplasm fund of fruit trees, berries and strawberry from Romanian collections]. Pământul. Piteşti, pp. 93-117 (in Romanian).

Butac, M., Militaru, M., Budan S., Sumedrea D. (2010). A survey of the genetic resources used in Romanian plum breeding programme. Ann. Univ. Craiova, XV (XLXI), 120-126.

Butac, M., Botu, M., Militaru, M., Budan, S. (2011). Romanian germplasm fund and its use in plum breeding program. Scientific papers, RIFG Pitesti, vol. XXVII.

Butac, M., Bozhkova, V., Zhivondov, A., Milosevic, N., Bellini, E., Nencetti, V., Blazek, J., Balsemin, E., Lafarque, B., Kaufmane, E., Gravite, I., Vasiljeva, M., Pintea, M., Juraveli, A., Webster, T., Hjalmarsson, I., Trajkovski, V., Hjeltnes, S.H., Lakatos, T. (2013). Overview of plum breeding in Europe. Proceedings of the Second Balkan Symposium on Fruit Growing, Piteşti, Romania. Acta Hort., 981, 91-98.

Cociu, V., Botu, I., Minoiu, N., Pasc, I., Modoran, I. (1997). Prunul [Plum]. Conphys (in Romanian). 434 pp.

Coman, M., Butac, M., Sumedrea, D., Dutu, I., Iancu, M., Mazilu, Cr., Plopa, C. (2012). Plum culture in Romania - current and perspectives. Acta Hort., 968, 25-32.

Dutu, I., Parnia, P., Viscol, I. (1993). Corcoduşul — sursa valoroasa pentru selectia de noi portaltoi pentru prun [Myrobalan — valuable source for the selection of new plum rootstocks]. In: Scientific papers "Plum days". $7^{\text {th }}$ edn. Rm. Valcea (in Romanian).

Kaufmane, E., Rubauskis, E., Skrivele, M. (2007). Influence of different rootstocks on the growth and yield of plum cultivars. Acta Hort., 734, 387-391.

Maggioni, L., Lateur, M., Balsemin, E., Lipman, E. (2010). Report of a Working Group on Prunus, Eight Meeting, Forli, Italy. Available from: http://www.ecpgr.cgiar.org/fileadmin/bioversity/publications/pdfs/ 1428_Report_of_a_working_group_on_Prunus_Eighth_Meeting_7-9_September_2010_Forli_Italy.pdf (accessed 20.04.2019).

Mazilu, Cr., Dutu, I., Mladin, Gh., Ancu, S., Coman, M., Rovina, A., Plopa, C. (2013). Achievements and prospects regarding vegetative rootstocks breeding at the Research Institute for Fruit Growing Pitesti, Romania. Acta Hort., 981, 407-412.

Sosna, I. (2002). Growth and cropping of four plum cultivars on different rootstocks in South Western Poland. J. Fruit Ornam. Plant Res., 10, 95-103.

Received 28 January 2019

Accepted in the final form 19 April 2019

\section{PLŪMJU GENĒTISKIE RESURSI UN SELEKCIJA RUMĀNIJĀ}

Rumānijā aug̣̣augu izvērtēšanas un saglabāšanas aktivitātes tika uzsāktas 1970. gadā, lai ierobežotu bioloğiskās daudzveidības samazināšanos. Genētiskie resursi izvietoti divās vietās: Augḷkopības zinātniskajā institūtā Pitešti — 642 vienības un Valesijā — 361 vienība, kas reprezentē savvaḷas sugas, vietējās populācijas, šḳirnes, atlasîtu selekcijas materiālu un potcelmus. No šo kolekciju ġenētiskajiem resursiem selekcijā izmantotas plūmju šķirnes 'Grase de Becs', 'Carpatin', 'Ialomita', 'Kirke', 'Wilhelmina Späth' (rezistencei/tolerancei pret Plum pox vīrusu); 'Vinete româneşti', 'Tuleu timpuriu', 'Anna Späth' (vēlai ziedēšanai), 'Tuleu gras', 'Vâlcean' (augḷu kvalitātei), 'Stanley', 'Pescâruş', 'Centenar' (ražỉbai) un 'Diana' (pašauglībai). Plūmju potcelmu selekcijas programmai izmantoti: 'Rosior văratec', 'Brompton', 'Renclod Verde', 'Pixy', 'Saint Julien A', 'Albe mici', 'Scolduş', 'Porumbar' u.c. Selekcijas aktivitātes, kas balstītas uz ǵenētisko resursu izmantošanu, rezultējušās ar 40 škirnēm un 11 ǵeneratīvi un veǵetatīvi vairojamiem potcelmiem. 